\title{
CLIMATE CHANGE: OPPORTUNITIES FOR COLLABORATIVE RESEARCH IN THE MAGELLAN AND ANTARCTIC REGIONS
}

\author{
CAMBIO CLIMÁTICO: OPORTUNIDADES PARA LA COOPERACIÓN \\ CIENTÍFICA EN LA REGIÓN DE MAGALLANES Y ANTÁRTICA
}

Ricardo Jaña ${ }^{1,2} \&$ Carlos Ríos $^{3}$

\begin{abstract}
RESUMEN
Se presenta un análisis de los principales contenidos e ideas surgidas durante la cuarta Sesión "Cambio Climático: Oportunidades para la cooperación científica en la Región de Magallanes y Antártica" del Coloquio Internacional "Cambio Climático en la Región de Magallanes y Antártica: Evidencia y Desafíos para el Futuro". Las presentaciones exploraron la disponibilidad y necesidades de datos, brechas y falta de conocimientos, las sugerencias de temas y objetivos en el planeamiento de nuevas investigaciones asociadas a la comprensión del fenómeno del cambio climático. Como conclusiones generales se ha reconocido el gran valor de las señales e intensidad de los cambios ambientales que se observan hoy en sitios particulares de esta vasta región geográfica. Al mismo tiempo se sugiere, debido a la supuesta riqueza de una no bien evaluada biodiversidad regional y de los inciertos impactos futuros del cambio climático sobre sus especies, que se cuenta con una invaluable fuente de condiciones que permiten la búsqueda de respuestas a preguntas globales y que permiten una ventajosa realización de investigación científica en esta menos contaminada naturaleza. En este contexto surgió con prioridad la alternativa de crear una red para fomentar la cooperación y la investigación del cambio climático y su impacto en la biodiversidad de la Región de Magallanes y Antártica Chilena. El territorio de la Región de Magallanes y Antártica Chilena es un área singular donde se producen intensos cambios ambientales respecto a otros lugares del Planeta, debidos al cambio climático. Esto representa para la ciencia no sólo una oportunidad de estudiar las causas y mecanismos del fenómeno aquí en el lugar de la alerta temprana, sino que también representa una oportunidad para trabajar unidos y usar la cooperación científica para contribuir al avance de la ciencia.

Palabras clave: Cambio climático, investigación científica, cooperación científica, Antártica, Región de Magallanes.

\footnotetext{
Departamento Científico, Instituto Antártico Chileno.

Fundación CEQUA.

Instituto de la Patagonia, Universidad de Magallanes.
} 


\begin{abstract}
An analysis of the main points and ideas arising during the fourth session "Climate Change: Opportunities for scientific cooperation in the Region of Magallanes and Antarctica" of the International Colloquium "Climate Change in Magellan and Antarctic regions: Evidence and Challenges for the Future" are presented. These explored the availability and data needs, gaps and lack of knowledge, suggestions for topics and objectives in the planning of new research associated to understanding of climate change phenomenon. As general conclusions, have been recognized the greater value of signals and intensity of environmental changes, happening nowadays in special sites of this vast territory. At the same time, because of supposed richness of not well assessed regional biodiversity and of the uncertain climate change impacts' on its species, an invaluable source of conditions are provided to contribute to the answering of global questions and to support advantageous scientific research in this less-polluted nature. In this context, was supported with priority the alternative of creating a network for research for climate change and its impact's on biodiversity of Magellan and Antarctic Region. The Magellan and Antarctic Region territory is a singular area where environmental changes are occurring in an intensified level respect to other places of the Planet. This is not only an opportunity for the science to study causes and mechanisms of the phenomena here in the early warning area but also represent an opportunity to work together and use the scientific cooperation to contribute to the understanding and advancing of science.
\end{abstract}

Key words: climate change, scientific research, collaborative research, Magellan Region.

\section{INTRODUCTION}

One of the principal objectives to achieve by the International Colloquium "Climate Change in Magellan and Antarctic Regions: Evidence and Challenges for the Future", it was to recognize the opportunities to implement collaborative-research on climate change at the Magellan Region territory. According to this intention, the Session 4: "Climate Change: Opportunities for Collaborative Research", was planned to disseminate the last findings on relevant topics associated to the climate change research and to explore potential opportunities for future scientific cooperation. Thus, three internationally recognized relevant scientists were committed to provide a review of the state of the art of scientific research in the Antarctic Peninsula and Magellan Region. Hence, the program was privileged to offer the lectures "Ice core reconstruction of Antarctic climate change and implications" by Prof. Dr. Paul Mayewski, who was awarded SCAR Medal for Excellence in Antarctic Research and is Director of the Climate Change Institute, University of Maine, USA; "Climate change in Antarctic and Magellan regions: fields and goals of scientific cooperation" by Prof. Dr. Wolf Arntz, researcher (Emeritus) of the Alfred Wegener Institute for Polar and Marine Research, Bremerhaven, Germany, and "Network of atmospheric observation stations in Antarctica: international collaboration for climate change research" by Dr. Jorge Carrasco, Peace coNobel Laureate (2007), GCOS-UNEP Leader South America Focal Point, Deputy Director of Dirección Meteorológica de Chile.

\section{SESSION DEVELOPMENT}

The presentations gave special focus on considerations about observational data needs, lacks or gaps of knowledge, presence of under-represented disciplines, as well as, the suggestion of possible fields and goals to consider in the planning of new research to develop in this vast geographical region. After their presentations a round table meeting was organized to answer questions and to address the interchange of ideas on potential scientific cooperation.

\section{Prof. Paul Mayewski}

Explanation of a large number of results gathered from multidisciplinary climate change research, leaded or contributed by Prof. Mayewski, demonstrate the importance of climate reconstruction based on ice cores evidence because their special 
characteristic to perform the accumulation of the environmental chronicles of the past. At the same time, the interpretation of these records provide useful information to other studies concerned with process and mechanisms of geo-systems' elements and with their dynamic interactions.

Nowadays available results describe past climate conditions based in several well known deep (>3.000 m depth) ice cores drilled-out mainly in central Antarctica. Used analytical methods provide a good resolution for the sampling of some 50+ traces elements in parts per billion, trillion and quadrillion, to document parameters of the environment at those times. Derived information from sampled proxy data extends temporal records to the past up to ca. 800 thousand years BP reporting eight glacial cycles in Concordia (Dome C) Station location. Nevertheless, in general the spatial distribution of these records still is poor and does not cover for example, the long latitudinal gradient of the Antarctic Peninsula region.

In modern times, chronological sub annually resolution of records, report evidence of natural and anthropogenic influence on atmosphere chemistry composition levels. For example, evidence show variations on concentration levels of key elements in connection with ENSO events, with changes of atmospheric circulation patterns, and events of extracontinental sources as like blowing dust, volcanic eruptions and man made events as forest burning and uranium mining.

Nevertheless, he call attention to that there is still a lack of information and a poor knowledge of the spatial variability and temporal complexity of Antarctica climate parameters within the global system, crucial for example to feed models for the prediction of regional climate in the future.

These ideas were identified as an opportunity to create alliances for international scientific cooperation and implement research on these relevant issues that contribute to global science.

\section{Prof. Wolf Arntz}

In his presentation Dr. Arntz highlighted the importance of international cooperation based on the experience of several German research groups that particularly study the Antarctic marine ecosystems. For these activities the Magellan Region is an obliged place for a high number of foreign scientists. This fact should facilitate the study of ecologic, evolutionary and geologic relations between Antarctica and the southern tip of South America.

He argued that is possible to recognize a series of research lines: latitudinal gradients, potential invasive species, the effect of Polar Front in distributions range limits of animals between Antarctica and Magallanes, native species/exotic species relation, glacier effects on distribution patterns and abundance of biota; that connect Antarctica and southern South America. At the same time, was pointed that existence of an international cooperation, favored by the Antarctic Treaty System, should stimulate the share-use of the available Antarctic facilities.

\section{Dr. Jorge Carrasco}

Dr. Carrasco in his talk gave a number of examples that describe current availability of global climate information, based on atmospheric, terrestrial and oceanic datasets, continuous and integrated, having free access on Internet. This capability is diminished by individualism in the use of information and a low involvement of Chile by its own stations in the current air-, land- and ocean-international-networks. Example of this situation is that only one Chilean glacier is included in the Mass Balance database of the World Glacier Monitoring Service, despite Chile concentrates over 20.000 square kilometers of glaciers on its South American territory.

One of the main constrains for climate change studies in Polar Regions is the scarcity of environmental data. This situation is because most of the instrumental stations records start being operative from the fifties. On the other hand, there is a lack of data records to the inland areas because stations were located in coastal areas. A similar situation happen in the south-American sector of the Region where a lack of climatic data exist at Southern Patagonian and Cordillera Darwin icefields because does not exist meteorological stations installed on this areas. International concern on climate change impacts has produced a great number of endeavors to monitor and to collect standardized, well-spatially-distributed environmental data in order to document and to describe variability and trends of the phenomenon. The World Meteorological Organization (WMO) and the United Nations Environmental Program (UNEP) together with other related organizations have been 
promoting the establishment of the Global Climate Observing System (GCOS) network. This program has defined to observe a number of 50 key variables to monitor and detect climate changes on sensitive localities acting as benchmarks sites across the Planet. This effort will allow among several other important objectives: to improve predictions of trends for next decades, contribute to attribute correctly causes of climate changes, provide applications and services for the economic sustainable development, and to meet the international conventions requirements signed by countries as like by Chile in the United Nations Framework Convention for Climate Change (UNFCCC).

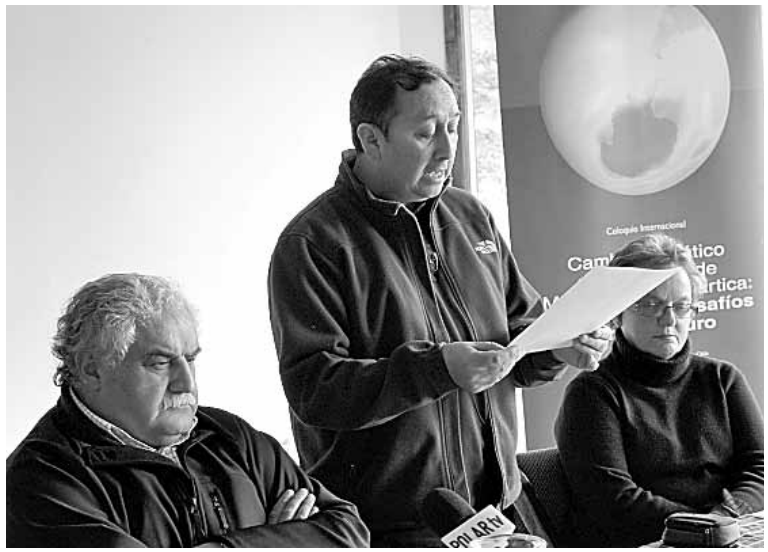

\section{CONCLUDING REMARKS}

One of the main general conclusions prevailing through all presentations of this session and most of the comments provided during the round table debate is that climate change is considered more a challenge than a threat. Nevertheless, a more realistic understanding of its effects and consequences require more scientific evidence. For this it was devised the need of the starting and maintenance of a long term environmental monitoring without the unique intention to record biotic and abiotic variables but with the purpose to start a program of sound scientific projection.

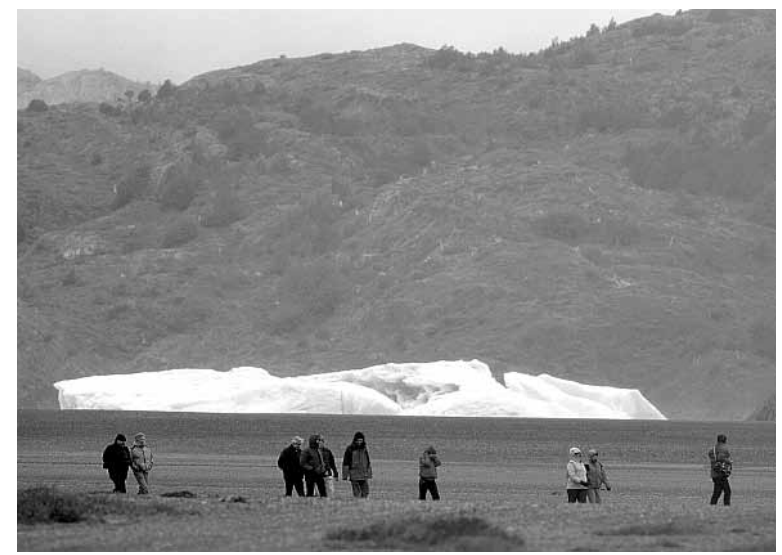

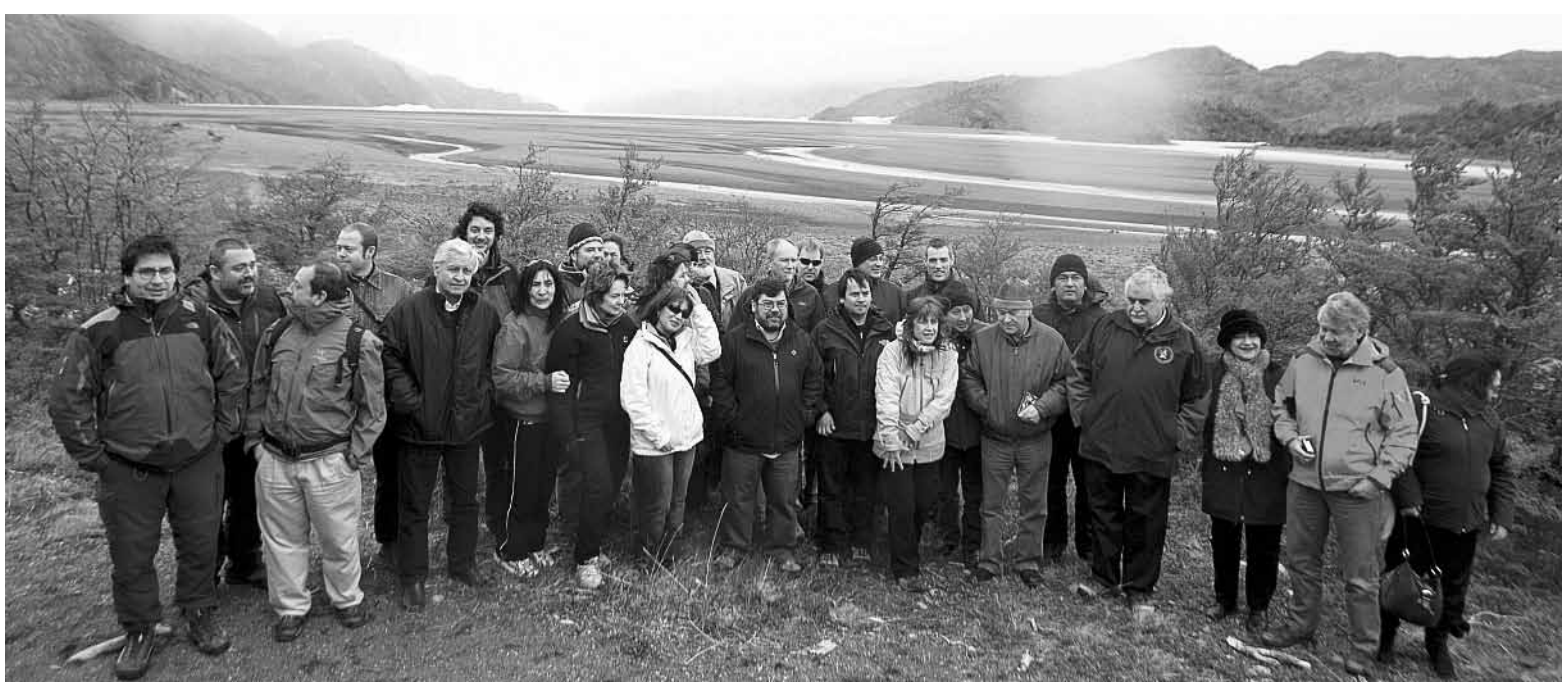

Fig. 1. The Magellan Declaration "A Calling to Action on Climate Change and Bio-diversity Research in the Region of Magallanes and Antarctica", was read and signed on Torres del Paine National Park on 31 October 2009. This instrument to strength the scientific cooperation was a meaningful asset early achieved by the International Colloquium, recognizing the importance of global changes and expressing concern of scientists and local authorities on climate change impacts that affect this territory and the rest of Planet. 
The scientific base must be clearly oriented to elucidate effects and consequences of climate change but also economical and political dimensions should be addressed. On this respect and mainly because of societal consequences associated to climate change, it is required that science approaches to society. One example on this respect is the case of this colloquium that was open to all community.

Also was emphasized the need that science should link with community through outreach but also to whom take decisions at regional level. The political authority is a very important actor in this type of public debates reason why it is needed a more active participation involving them. In order to include the whole community into the climate change issues should be seek some ways to distribute widely the information reported by the Intergovernmental Panel on Climate Change. The participation of an informed and responsible community can be critical to define priorities, where environmental education involving actively youth sectors of society also appears to be relevant.

It was agreed that it is fundamental to reinforce the regional scientific capacity to promote the development of new research initiatives related to climate change, maximizing the frame of cooperation at all possible levels.

During the debate, also was registered an entry in terms that should be appreciated that CONICYT could review their current policy and includes new elements to promote the scientific development in all the country, replacing the system based on individual projects that rather it promotes growth of "scientific consanguinity" and scientific centralism in the country, that is not conducive to regional developments.

The Magellan and Chilean Antarctic Region posses a considerable importance in the country as an area affected by climate change, as well as, has an ecologic value widely recognized. From this point of view, it is needed a cooperative joint scientific work having basis in regional (political) scientific autonomy, able to define specific priority lines of action. In this context, was supported with priority the alternative of creating a network for research for climate change and its impact's on biodiversity of Magellan and Antarctic Region.

The Magellan and Antarctic Region territory is a singular area where environmental changes are occurring in an intensified level respect to other places of the Planet. This is not only an opportunity for the science to study causes and mechanisms of the phenomena here in the early warning area but also represent an opportunity to work together and use the scientific cooperation to contribute to the understanding and advancing of science.

\section{ACKNOWLEDGEMENTS}

Our deep thanks to CONICYT and Magallanes Region Government for funding the International Colloquium. To all key-note speakers, who provided brilliant lectures to communicate results and review of state of the art in required topics, we express to them our high appreciation. We are thankful of the University of Magallanes and the Chilean Antarctic Institute to promote the building capacity of its scientist and to promote the advance of science in the global change research. Our special gratitude to Alejandra Mora and Beba Garcia, they provide a very professional support. Finally, our recognition to many anonymous collaborators that did a great job allowing the accomplishment of this very successful meeting. 
R. JAÑA \& C. RÍOS 